\title{
Conditions for the Spread of the Peyote Cult in North America
}

\author{
By $\AA$ KE HULTKRANTZ
}

As is well known large parts of native North America with the Prairies and Plains in the middle of the continent as the centre of diffusion have constituted, since the end of the last century, the scene of a nativistic Indian movement, the so-called peyote cult. ${ }^{1}$ Through the mediation of Indian tribes like the Kiowa, Kiowa Apache and Comanche (who al so to a large extent were responsible for its ritual form) the peyote cult has spread from the areas of the Rio Grande northwards over the whole Prairie and Plains area up to the Saskatchewan River. In the west it has gained ground among Great Basin groups and among the Navajo and Taos Indians on the high plateaus of Arizona and New Mexico. In the east some groups of the former woodland Indians at the Great Lakes have been won for peyotism. The number of peyotists in an ethnic group may fluctuate; but often the main part of the Indians belong to the peyote cult.

The peyote cult—or, as it should have been called, the peyote religion ${ }^{2}-$ is named after its central cultic action, the consumption (by eating, drinking or smoking) of the spineless cactus peyote (Lophophora williamsii). This cactus that may be found growing wild along the Rio Grande and in the country south of this river contains several alkaloids, among them the morphine-like, hallucinogeneous mescaline. Peyote produces colourful visions, hallucinations of movement and audition, strengthens the capacity for observation, and brings forth sentiments of solidarity and personal surrender.

\footnotetext{
1 The term nativism is here used in a very wide sense, corresponding to Voget's "reformative nativism" that presupposes a synthesis of traditional and alien cultural components (Voget, 250). "Traditional" includes in this case not only tribal but also general Indian traits. ${ }^{2}$ It is unfortunately due to A. L. Kroeber's influence that so many religions, in particular of a sectarian character, have been misnamed "cults" in North American anthropology.
} 
In pre-Columbian days peyote was used in connection with certain public ceremonies among the Indians of Mexico, for instance, at the annual thanksgiving ceremonies. In its modern form the peyote ritual constitutes a religious complex of its own, considered to promote health, happiness and welfare among its adepts. Many peyotist groups have (since 1918) joined the peyote ecclesiastical organisation, The Native American Church. Today, the peyote cult is almost the only one besides shakerism of the revivalistic Indian movements of the nineteenth century still prevailing. Its diffusion is steadily going on, and in many reservations where it has had a hold for some time it is gaining more and more converts. ${ }^{3}$

The peyote cult has been described and analysed in several instructive works, foremost among them the monographs by La Barre and Slotkin. ${ }^{4}$ Most problems of a major scope have been dealt with in these publications. However, one special problem seems to me to deserve a greater attention: whether the spread of peyote and the peyote cult was facilitated by particular historical, social or other conditions in Indian North America, or even whether the cult had a precursor. In the following I shall briefly illuminate this problem and to this end formulate two leading questions: what were the conditions for the diffusion of the peyote cult? what particular factors accounted for the spread of the cult to just those areas that were mentioned above, and for its obstruction in other areas? It is obvious that in many respects the task undertaken here is too complicated to be dealt with adequately in a short article. Only the main lines of my investigation can therefore be presented here. A more detailed account will follow in a separate paper already completed and waiting for publication.

Students of peyotism have suggested a variety of preformative factors, but the dissension between their opinions is considerable. It is safe to say that most interpreters are agreed upon one thing, viz, that the growth and spread of the peyote cult should be seen as a concomitant of the radical change that Indian society in the Plains and Prairie area has undergone during the past

\footnotetext{
${ }^{3}$ Conversely, in many other reservations the peyote cult is receding. The history of peyote has always been a backwards and forwards movement.

${ }^{4}$ See e.g. La Barre 1938 and 1960, Slotkin. Cf. also Gusinde. The leading authority is La Barre The best discussions of the peyote cult in a tribal setting may be found in Aberle 1966, $1 \mathrm{ff}$; 1957,ff and Stewart, 1 ff.
} 
hundred years. In this perspective the peyote cult offers an example of religious acculturation, that is, religious change following a "complete culture-contact" (or complete interaction between two different cultures). ${ }^{5}$ There is however no unanimous opinion among researchers as to what factors had the decisive influence in this process. Most students are inclined to single out one or two factors. We shall here survey the main views on this matter, and then continue with factors that have been referred to as proofs of a religio-historical continuity.

If, first, we concentrate on proposed factors of acculturation it goes without saying that external changes in the environment have facilitated this process, and thereby peyotism. Thus, Aberle and Stewart have primarily explained peyote diffusion with reference to geographic availability-which is an important ecological point of view-and possible communications. ${ }^{6}$ As we know, railroads and dustroads for wagons quickly spread over the central distribution area-the Plains and Prairies-in the 1860's and thereafter, thus transforming the inter-communicative possibilities here. This is exactly the time when the peyote cult began to spread. The diffusion took place between reservations, since Indians were now confined to such areas.

Many authors have adduced circumstances that should underline the role of peyotism in the ideological adaptation of Indian groups. Some points that have been proposed are absurd, for instance, the claim that the peyote cult strengthens the old tribal religion in an acculturative situation. Such a stand disregards the fact that peyotism is an intrusive, new religion that shakes the tribal solidarity and some old religious values. If, however, the reference is not to the traditional tribal religion but to traditional Indian religion seen as a token of Indian identity - what has been called pan-Indianism-the standpoint is more realistic. As a matter of fact, peyote has been an instrument for the creation of this feeling of Indian commonness; ${ }^{7}$ séances often include members of many tribes, and the sensation of intimacy and transference that was earlier said to accompany the eating of peyote contributes to intertribal understanding among peyotists.

\footnotetext{
${ }^{5}$ For the definition, see Hultkrantz, 15. Aberle however asserts that acculturation was a non-essential factor for the growth of peyotism among the Navajo (Aberle 1966, 243). Cf. further below.

${ }^{6}$ Cf. Aberle 1957, $1 \mathrm{ff}$.

${ }^{7}$ Cf. Shonle, Ruth, 57.
} 
A student and peyotist like Slotkin has seen peyote as a weapon in the Indian fight against white domination. ${ }^{8}$ Not in any militant sense, however; peyotism, he says, "provided a supernatural means of accommodation to the existing domination-subordination relation". 9 Peyote provided the ideological foundation for the opposition to white supremacy.

Some observers think that in this encounter peyote legitimated Indian efforts by appearing as a counterpart to Christianity. It is commonly said among peyotists that just as the whites learned the right way from Christ, Indians learned it from peyote. In other words, two equal religions confront each other, the one as good as the other. The peyote religion has the advantages that it is native Indian and well adapted to the prevalent situation. In comparison with orthodox Christianity it is much easier to learn-some few concepts like God, Jesus, thunderbird and (mother) peyote, some ethical prescriptions, a very elementary ritual-and it is inspirational. It meets traditional Indian requirements in a way orthodox Christianity never does.

And still, there is the opinion among scholars that the peyote cult attained its position of a pan-Indian, ideological institution in virtue of its Christian affinities. There is no doubt that a central part of the ideology is, as could just be seen, decidedly Christian. We know also that Ute and Winnebago peyote groups have made petitions to Christian organisations to be approved as members of the Christian church. Some students who, although not Indian, regard themselves as peyotists, in particular Slotkin, define the peyote cult as an Indian version of Christianity. ${ }^{10}$ This is a surprising statement. For all we know there were only a few Christian traits among the Kiowa and Comanche when the peyote cult spread from this nucleus area around $1890 .{ }^{11}$ In later days it assumed a veneer of Christian ideology, as La Barre has underscored..$^{12}$ Altogether it is a question of an additive process, not a fundamental change of the ideological pattern. As such, however, it most certainly has stimulated the diffusion of the peyote religion.

If thus the importance of the social factors of acculturation has been emphasized by many writers in their assessment of peyote distribution,

\footnotetext{
${ }^{8}$ Cf. Slotkin, $17 \mathrm{ff}$.

${ }^{9} \mathrm{Ib} .20$.

${ }^{10}$ Cf. ib. 46.

${ }^{11}$ Cf. Mooney, 65.

12 Cf. La Barre 1971, 22.
} 
others have put the adaptation of the individual to a new cultural situation in the foreground. They have proceeded from the fact that man in acculturation suffers from a cultural shock; and Geertz is perhaps quite right when he pinpoints suffering as a gateway to religion. ${ }^{13}$ The arrival of European civilisation deprived the Indians not only of the externals of traditional culture but also of existential meaning and religious values. The loss was expressed in spiritual terms among the Plains Indians: they were, says Ruth Underhill, "apparently deserted by their spirit helpers". ${ }^{14}$ The scientists who have analysed the situation think they have found deeper causes behind such manifest religious formulations: anxiety for life and heal th, or for social and personal security, or for economic safety. The dissolution of these anxieties should then be offered by peyote.

There is, for instance, the thesis proposed by Richard Schultes, a botanist who has written several articles on the peyote cult, that peyote spread as a remedy, a medicine to ensure health and survival. ${ }^{15}$ Now, Schultes does not mean that it was because of narcotic qualities that peyote met such a quick response; from a medical point of view peyote is not narcotic since the use of it does not create any dependence whatsoever (a fact not always recognized by American courts). Schultes is concerned with the Indian idea that peyote is medicine. There is much evidence at our disposal that persons have joined the peyote cult for curative reasons. However, Schultes has neglected to place the curative aspect into its spiritual frame: medicine is for the Indians a comprehensive concept referring to origins in visions and supernatural qualities. ${ }^{16}$

Another proposition is that the peyote cult is a refuge for people who suffer mentally from cultural loss. An investigation made at the Navajo reservation in the Southwest has indicated that peyotists show more distur-

\footnotetext{
${ }^{13} \mathrm{Cf}$. Geertz, 19. His dictum that the problem of suffering is "not to avoid suffering but how to suffer" is too narrow however. The theory of cultural shock comes close to "the cultural disintegration theory", so called by Stewart who does not find it adequate to explain peyote diffusion, however. This theory that has been applied in practice by e.g. Kroeber says that "peoples experiencing cultural disintegration and degradation will readily accept new religions, especially those which promise the miraculous restoration of former conditions of life" (Stewart, 90). Cf. also e.g. Ljungdahl, 168.

${ }^{14}$ Underhill, Ruth, 143.

${ }^{15} \mathrm{Cf}$. Schultes, $1 \mathrm{ff}$.

${ }^{16}$ Cf. La Barre $1960,52,54$.
} 
bances in their dreams than other individuals. ${ }^{17}$ The same lack of stability has been demonstrated among Menomini on a reservation in Wisconsin: Rorschach tests provide evidence that peyotists as a transitional group in society have difficulties in coping with cultural change and therefore, according to the investigators, exhibit great anxiety. ${ }^{18}$ There is, in the view of the present author, reason to believe that the real cause of this anxiety is the loss of the old, tribal religious value system which could not be restored in the peyote cult. Confessions of sins, i.e. transgressions of the ethical code of the peyote religion, may however to a certain point reduce this anxiety. On the social side, peyote membership may be a ladder to distinction both for the old elite, at least on the Plains, and for newcomers striving for status. Of course, the religious problem is not solved in this way.

Not surprisingly some authors have developed the theory that peyote has been resorted to in a situation of economic depression. This theory could naturally be linked with the general theory of deprivation on account of cultural loss in acculturation. However, one author, Aberle, denounces the latter at the same time as he embraces the former as cause of Nav ajo peyotism. Aberle has observed that the peyote cult was established at the same time as there was a forced stock reduction (of sheep and goats) in the Navajo country, in the 1930 's; he also points out that the Navajo at that time were the least acculturated tribe in "the United States. ${ }^{19}$ However, since the action was ordered by white authorities it is difficult to avoid the conclusion that acculturative pressure was responsible for the weakened economic situation that emerged. It is important to note that it was not the economy as such, but the loss of cultural stability and religious balance that drove the stock owners into peyotism. For, as Aberle remarks himself, the elimination of so much of the stock upset the world order. ${ }^{20}$

After having observed factors that could account for social and individual adaptation to peyote we shall, finally mention two general ideological patterns into which, according to several authors, the peyote cult could easily be framed. We are here thus dealing with arguments for a religio-historical continuity.

\footnotetext{
17 Cf. Dittmann, 1 ff.

${ }^{18} \mathrm{Cf}$. Spindler, $1 \mathrm{ff}$.

$19 \mathrm{Cf}$. Aberle 1966, 3, 243, $308 \mathrm{f}$.

20 Cf. ib., 200.
} 
La Barre, Howard and others have noted that a "mescal-bean cult" preceded the peyote cult in the central and southern parts of the Prairie and Plains area. ${ }^{21}$ The mescal bean or "red bean" is (the fruit of) an evergreen, Sophora secundiflora. It was consumed in the same way as peyote and brought on vomiting - to some peoples, like the Iowa, considered ceremonial cleansing-and hallucinations. The mescal eaters formed secret societies, and their ritual paraphernalia were those of the later peyotists. It seems indeed very likely that the peyote cult was formed on the pattern of the ancient mescal bean cult. This would also explain why the mescal and the peyote have so often been confused in the debate. ${ }^{22}$

The importance of the vision complex in furthering the course of the peyote cult was pointed out by Ruth Shonle as early as 1925 . In particular she aligned its diffusion on the Prairies and Plains with the vision quest here, since in this area the seeking of visions preceded all kinds of significant undertakings. ${ }^{23}$ Some students have followed suit, but many who have developed other ideas on the spread of peyote disagree. There are especially two objections that have been raised by critics: that peyote has spread outside the true vision complex area, and that visions have little meaning in the peyote cult. The validity of the first objection has been illustrated with examples taken from the Southwest area, traditionally an area where, at least among the agricultural Pueblo Indians, subjective experiences have played a subordinated role. ${ }^{24}$ If in this area we find the peyote cult represented in the pueblo of Taos this may be defended by referring to its peripheral position and the influx of Plains cultural elements. However, the recent spread of peyotism to the Navajo Indians offers a more delicate problem. The Navajo have a negative attitude to visions, ${ }^{25}$ and Aberle plays down the role of visions in the Navajo peyote cult. ${ }^{26} \mathrm{We}$ know, however, that peyotism had great difficulties to gain ground on the Navajo reservation, and that it

\footnotetext{
${ }^{21}$ Cf. La Barre 1938, $105 \mathrm{ff}$; Howard 1957, $75 \mathrm{ff}$. In later publications the two authors have disagreed in some matters of diffusion, partly due to misunderstandings. Cf. La Barre, 1960, 48, and Howard 1960, $84 \mathrm{f}$.

${ }^{22}$ Cf. Howard 1957, 86.

${ }^{23}$ Cf. Shonle, Ruth, 53, $58 \mathrm{f}$.

${ }^{24} \mathrm{Cf}$. Benedict, Ruth, 40.

${ }^{25} \mathrm{Cf}$. Haile, $1 \mathrm{ff}$.

${ }^{26}$ Cf. Aberle 1966, 6.
} 
was introduced very late. A similar reasoning is applied by La Barre in defense of Miss Shonle's standpoint. ${ }^{27}$

The second objection is tied up with the first one, for it is just in an area like the Navajos' that the reduced significance of visions in the peyote cult can be demonstrated. ${ }^{28}$ Nevertheless, it is hard to see how a direct experience with the supernatural in visions can have as little meaning as the propounders of this thesis think it has.

\section{III}

We have seen that an array of motivations has been mobilized in order to account for the accommodation of the peyote cult on North American Indian reservations. Some of them appear less convincing, others well taken. We certainly come closer to the truth if we proceed from the assumption that several of these propositions combined indicate the conditions for the spread of the peyote cult. A similar stand has been taken earlier by authors like La Barre, Ruth Shonle, Arth and Slotkin. They do not, however, La Barre excepted, take stock of other possibilities than those they find useful. A survey of opinions like the one here presented seems to the present author more likely to bring creative results. Otherwise, Slotkin's list of causes is both elaborate and suggestive (although perhaps too much attention is paid to ethical and sociological issues) ${ }^{29}$

An attempt will now be made to assess the conditions for the diffusion. It is based on some of the earlier proposals and adds some further points of view.

In this connection it is important to make a distinction between the functions of peyote in a certain society and the original circumstances at the time when peyote was accepted by this group (or by certain individuals in this group). In other words, I do not find certain psychological considerations very helpful which take their departure from peyotist reactions in a modern Indian community. The functions of the peyote cult change with locality and time in one and the same tribal group. ${ }^{30}$

\footnotetext{
27 Cf. La Barre 1960, 51.

28 Cf. Stewart, 86.

${ }^{29}$ Cf. Slotkin, $18 \mathrm{f}, 35 \mathrm{ff}$.

${ }^{30}$ The interesting problem of differential diffusion has been observed by several anthropologists, for instance, George and Louise Spindler and Wesley Hurt, Jr.
} 
Furthermore, consistent with this point is another, that any proposition regarding the general conditional factors of peyote distribution should ignore special local developments, unless these illustrate the former. Since the distribution is so intimately tied up with the Prairie and Plains area-or, to be more exact, the Plains Indian reservations-there should be a heavy reliance on factual materials from this region. However, other regions are interesting not least because they demonstrate factors operative in impeding diffusion.

Finally, there is reason to lay more stress on religion and faith in evaluating the conditioning factors. Among the Omaha, says Malcolm Arth, "the (Peyote) religion is first and foremost an expression of the spiritual and aesthetic needs of many of the people".$^{31}$ It is certainly so among all groups that have adopted peyotism, although, when reading many of the papers that have been quoted in the foregoing, one often receives the impression that religion is forgotten. Or, the manifest religion is reduced to latent personality trouble. In my discussion of cultural shock and anxiety, above, I suggested that disturbance of religious values lies behind these states. My anthropological colleagues have, to my understanding, been too eager to avoid the obvious conclusion.

After these considerations I offer the following scheme as my contribution to the understanding of the factors that paved the way for the peyote cult.

1. The change in the North American Indian situation at the end of the nineteenth century supplied new facilities for religious innovations and for the introduction of a foreign religious movement, the peyote cult. Slotkin has mentioned some of the salient features in the new situation: cessation of intertribal warfare (and, we may add, of wars with the whites), settlements within reservations, often bordering on each other (and several tribes joined in one reservation, vide the Indian Territory, or Oklahoma), easy travel on highways and railroads, use of English as a common language, and use of mail service by those who can read and write. ${ }^{32}$

In the cultural and religious fields, these environmental changes had various repercussions that may be covered with the word acculturation. Religious acculturation implied a demand for continued religious faith in

\footnotetext{
${ }^{31}$ Arth, 25.

32 Cf. Slotkin, 19.
} 
moulds that were both anchored in the past heritage and adapted to new ideas. We note specifically:

a. There was a cultural change, sometimes bordering on cultural loss. The old religious rites, for instance war rituals, buffalo-hunting rituals, were not adapted to the new situation on the reservations. The major Plains Indian ceremony, the sun dance, was forbidden or repressed by the white authorities. At the same time the men now found leisure time to indulge in ceremonialism. It seems that the peyote rite filled in the vacuum left by the sun dance.

b. There ensued a relativism of values, and this fostered a crisis that had to be overcome. The old religion was insufficient. So was white man's Christianity to those who did not want to be incorporated in the western civilisation. Peyote, with a structure like the Church and concepts competing with Christian ideas, offered a solution. At the same time incorporation of Christian concepts facilitated the acceptance of peyotism on reservations where Christian missions were influential.

2. The ideological structures of the vanishing Indian cultures constituted preformative patterns into which the peyote religion could be framed, or else, by which the peyote religion was blocked.

A. Positive adaptations. In these cases, mostly represented in the Prairie and Plains area, there was a rapport in structure and function between the old religious pattern and the peyote cult. Several examples could be adduced, but we single out the following:

a. The mescal bean cult which, as we have seen, had many features in common with the peyote cult, preceded the latter in the middle and southern parts of the Plains area. Indeed, there is archaeological testimony that the red bean cult existed in south-western Texas during the first millenium A.D. ${ }^{33}$

b. Ritual structure and ritual symbolism have on the whole been fairly identical in the whole area under consideration here, with the exception of the Great $\mathrm{Basin}^{34}$. They are also reflected in the peyote cult. As pointed out by La Barre, Slotkin and others, specific ritual traits in the peyote cult can be derived from Mexican Indian ceremonials, Apache and Kiowa rituals, mescal bean rituals and Christian rituals (prayer forms, Bible reading etc.).

${ }^{33}$ Cf. Campbell, 1 ff.

$34 \mathrm{Cf}$. Lowie, $231 \mathrm{ff}$. 
c. The preformative influence of the vision complex, or the vision quest pattern, should indeed be considered the most important single factor for the spread of peyotism, exactly as suggested by Ruth Shonle. In ascribing this importance to visions I want to stress that they should not be regarded as having an intrinsic value in themselves, but as constituting forms for a direct experience of the supernatural world-for it is this immediate contact and its blessings that mean so much. As one of my Shoshoni informants on peyote told me, the importance lies in the power, not in the vision. Seen in this perspective the Navajo peyote experiences also move along the pattern set by the visionary experiences.

The significance of the vision pattern for the acceptance of peyote may be best observed in the Plains area, the stronghold of the vision complex (cf. above). When the Indians moved to reservations the vision quest declined, and that for mainly two reasons. Firstly, the old, sacred places were no longer accessible, now being situated in white man's land $d^{35}$. Secondly, the reservation life meant an ideological change, and the acquisition in visions of guardian spirits for war, hunting of game and other formerly topical pursuits was experienced as superfluous. There was now a need for spiritual communion and a faith in Indian religious values on a more general scale. However, having been defeated in combat and exposed to competing ideologies the Plains Indians had difficulties in realizing their will to believe. The vision had been succeeded by the religious doubt.

In this deplorable situation the peyote cult was actualized. It was well adapted to the new situation on the reservations, and the old vision pattern could be transferred to it. However, within the general structure there appeared some novelties. The visions were no longer individualistic, as in the old nomadic and hunting culture, but were received in a collective frame, and this added, of course, to the visionary's sense of safety and spiritual reality. Furthermore, if formerly the vision quest had been associated with vicissitudes, and not always was successful, it was now a comparatively easy task, and visions were attainable for everybody who tried. Indeed, the peyote vision could be very strong, a true hallucination, and as such superior in quality and more compelling than earlier visionary dream ${ }^{36}$. Finally, the vision no longer revealed spirits and conferred special powers, except in

\footnotetext{
${ }^{35}$ There are exceptions. The Cheyenne, for instance, still seek visions at their sacred mountain, Bear Butte, in the Black Hills, far from the reservation.

${ }^{36}$ Cf. Hultkrantz in La Barre 1960, 57, note 4.
} 
some cases; it mediated a direct experience of a spiritual sphere of existence, and it showed in symbolical form a spiritual way of living. Sometimes the vision could tell the future, or it imparted a general consciousness and feeling of divine power.

B. Obstructive factors. In this context we shall review some patterns that were responsible for the restriction of peyote diffusion to certain areas, mainly the Prairie and Plains and the Great Basin, while the Southwest with some exceptions (Apache and Navajo, Taos) did not take part in the expansion.

a. Conservatism and traditionalism have everywhere constituted a hindrance to the diffusion of the peyote cult, but particularly so in the Pueblo area (or sub-area of the Southwest) where a well ingrained ceremonialism and an agrarian type of religion well adjusted to the needs of Pueblo culture and society had been left intact for many centuries. White expansion has only slowly infringed upon the Pueblo Indian traditions.

The individualism of the Plains Indians that admitted so many religious innovations was entirely absent here. But even on the Plains the peyote cult has represented something new and foreign when first known, and it has therefore been opposed by individuals as well as tribal councils. As time passed it gained in reputation, particularly so when it had been integrated with old cultic elements or obtained a Christian veneer.

b. Hierarchical structure has sometimes been a strong impediment. The medicine-men on the Prairies and Plains and in the Great Basin have occasionally tried to oppress peyotism sipce it threatened to take over their healing and divinatory functions, but with little success; after all, their position was already attenuated through the presence of other visionaries. In the Pueblo area, however, the richly differentiated priestly and healing associations put up an effective barrier against new institutional religious systems that upset the ruling order.

c. There have been other "psychotropic" (La Barre) means beside peyote, and where these prevailed they prevented the spread of peyote. Thus, the diffusion of peyote westward was checked by the presence of the Jimsonweed or toloache ${ }^{37}$.

3. Peyote had of course an attraction of its own, not in its taste or in the

37 Cf. Driver, 102.

6-752446 H. Biezais 
aethetic layout of its ceremonials - the former is horrid, the latter rather simple-but in its effects.

a. The peyote experience provides religious assurance, an assurance that is strengthened by the positive reactions of all those who partake in the rite. The experiences of coloured visions, voices, and strong positive sentiments to other peyotists present convince the participant of the ceremony of the supernatural quality of the herb.

b. As a consequence of its supernatural character all kinds of blessings are expected from peyote: good health, personal security, family happiness, endurable economic support, etc. These conditions are all thus considered in a religious perspective.

c. The peyote cult is characterized by great flexibility, not least in its conceptual system, and can therefore, in the long run, be integrated with different cultures. The Pueblo religions are however obvious exceptions to this rule.

d. The peyote cult furthers pan-Indianism, the Indian community in interests over tribal boundaries. Over great areas we find the peyote cult to be the creed of Indians of many nations, and members of different tribes may sit together at the same cultic meetings.

These are, as far as the present writer can see, the main conditions and the main obstacles, respectively, in the diffusion of the peyote cult. With all respect to those who think differently, I consider that to a large extent this diffusion took place because there was a religious situation that facilitated it. The foregoing short analysis, although incomplete, should have borne out this conclusion.

\section{Bibliography}

Aberle, D., 1966, The Peyote Religion among the Navaho. Viking Fund Publications in Anthropology 42. New York.

Aberle, D. \& Stewart, O., 1957, Navaho and Ute Peyotism: A Chronological and Distributional Study. University of Colorado Studies. Series in Anthropology 6. Boulder, Colorado. Arth, M., 1956, A Functional View of Peyotism in Omaha Culture. Plains Anthropologist 7.

Benedict, Ruth, 1923, The Concept of the Guardian Spirit in North America. Memoirs of the American Anthropological Association 29. Menasha.

Campbell, T., 1958, Origin of the Mescal Bean Cult. American Anthropologist 60, 1.

Dittmann, A. \& Morre, H., 1957, Disturbance in Dreams as Related to Peyotism among the Navaho. American Anthropologist 59, 4.

Driver, H., 1961, Indians of North America. Chicago.

Geertz, C., 1966, Religion as a Cultural System. A.S.A. Monographs 3. 
Gusinde, M., 1939, Der Peyote-Kult, Entstehung und Verbreitung. St. Gabriel-Studien 8. Wien-Mödling.

Haile, B., 1940, A Note on the Navaho Visionary. American Anthropologist 42, 2.

Howard, J., 1957, The Mescal Bean Cult of the Central and Southern Plains: An Ancestor of the Peyote Cult? American Anthropologist 59,1.

- 1960, Mescalism and Peyotism Once Again. Plains Anthropologist 5, 10.

Hultkrantz, $\AA$., 1969, Pagan and Christian Elements in the Religious Syncretism among the Shoshoni Indians of Wyoming. Scripta Instituti Donneriani Aboensis 3. Stockholm.

La Barre, W., 1938, The Peyote Cult. Yale University Publications in Anthropology 19. New Haven.

- 1960, Twenty Years of Peyote Studies. Current Anthropology 1, 1.

- 1971, Materials for a History of Studies of Crisis Cults: A Bibliographic Essay. Current Anthropology $12,1$.

Ljungdahl, A., 1969, Profetrörelser, deras orsaker, innebörd och förutsättningar. Diss. Stockholm Studies in Comparative Religion 10. Stockholm.

Lowie, R., 1915, Ceremonialism in North America. Anthropology in North America. New York.

Mooney, J., 1892, A Kiowa Mescal Rattle. American Anthropologist. O. S. 5.

Schultes, R., 1938, The Appeal of Peyote (Lophophora williamsii) as a Medicine. American Anthropologist 40, 4.

Shonle, Ruth, 1925, Peyote, the Giver of Visions. American Anthropologist 27, 1.

Slotkin, J., 1956, The Peyote Religion. Glencoe, Illinois.

Spindler, G., 1955, Sociocultural and Psychological Processes in Menomini Acculturation. University of California Publications in Culture and Society 5. Berkeley and Los Angeles.

Stewart, O., 1944, Washo-Northern Paiute Peyotism: A Study in Acculturation. University of California Publications in American Archaeology and Ethnology 40, 3. Berkeley and Los Angeles.

Underhill, Ruth, 1952, Peyote. Proceedings of the 30th International Congress of Americanists. London.

Voget, F., 1956, The American Indian in Transition: Reformation and Accommodation. American Anthropologist 58, 2. 